\title{
Structural models of vanadate-dependent haloperoxidases and their reactivity
}

\author{
MANNAR R MAURYA \\ Department of Chemistry, Indian Institute of Technology, Roorkee 247667 \\ e-mail: rkmanfcy@iitr.ernet.in
}

\begin{abstract}
Vanadium(V) complexes with hydrazone-based ONO and ONN donor ligands that partly model active-site structures of vanadate-dependent haloperoxidases have been reported. On reaction with $\left[\mathrm{VO}(\mathrm{acac})_{2}\right](\mathrm{Hacac}=$ acetylacetone $)$ under nitrogen, these ligands generally provide oxovanadium(IV) complexes $[\mathrm{VO}(\mathrm{ONO}) \mathrm{X}](\mathrm{X}=$ solvent or nothing) and $[\mathrm{VO}(\mathrm{acac})(\mathrm{ONN})]$, respectively. Under aerobic conditions, these oxovanadium(IV) species undergo oxidation to give oxovanadium(V), dioxovanadium $(\mathrm{V})$ or $\mu$-oxobis $\{$ oxovanadium(V)\} species depending upon the nature of the ligand. Anionic and neutral dioxovanadium $(\mathrm{V})$ complexes slowly deoxygenate in methanol to give monooxo complexes $[\mathrm{VO}(\mathrm{OMe})(\mathrm{MeOH})(\mathrm{ONO})]$. The anionic complexes $\left[\mathrm{VO}_{2}(\mathrm{ONO})\right]^{-}$can also be converted in situ on acidification to oxohydroxo complexes $[\mathrm{VO}(\mathrm{OH})(\mathrm{HONO})]^{+}$and to peroxo complexes $\left[\mathrm{VO}\left(\mathrm{O}_{2}\right)(\mathrm{ONO})\right]^{-}$, and thus to the species assumed to be intermediates in the haloperoxidases activity of the enzymes. In the presence of catechol $\left(\mathrm{H}_{2} \mathrm{cat}\right)$ and benzohydroxamic acid $\left(\mathrm{H}_{2}\right.$ bha), oxovanadium (IV) complexes, [VO $(\mathrm{acac})(\mathrm{ONN})]$ gave mixed-chelate oxovanadium(V) complexes [VO(cat)(ONN)] and [VO(bha)(ONN)] respectively. These complexes are not very stable in solution and slowly convert to the corresponding dioxo species $\left[\mathrm{VO}_{2}(\mathrm{ONN})\right]$ as observed by ${ }^{51} \mathrm{~V}$ NMR and electronic absorption spectroscopic studies.
\end{abstract}

Keywords. Structural models; haloperoxidases; vanadium complexes; reactivity of vanadium complexes.

\section{Introduction}

Recent interest in vanadium complexes stems from their potential therapeutic ${ }^{1-5}$ and catalytic applications. ${ }^{6-11}$ Modelling the structure and properties of vanadium-containing molecules have also influenced research on vanadium chemistry. Examples of interest in this context are the vanadate-dependent haloperoxidases ${ }^{12,13}$ and vanadium nitrogenases. ${ }^{14,15}$ Vanadate-dependent haloperoxidase enzymes e.g. Ascophyllum nodosum (isolated from brown algae), ${ }^{16}$ Corallina officinalis (from red algae), ${ }^{17}$ and Curvularia inaequalis (from fungi) ${ }^{18}$ have been structurally characterized and all of these show a high degree of amino acid homology in their active centres and thus have almost identical active site structures as shown in figure 1 for Ascophyllum nodosum as an example.

In these enzymes vanadium is covalently linked to the $\mathrm{N}^{\varepsilon}$ of an imidazolyl moiety of proximal histidine and to the axial $\mathrm{OH}$ group trans to the histidine which is further hydrogen-bonded to a distal ("catalytic") histidine and to water molecules. The overall geometry is trigonal bypyramidal with $\mathrm{O}_{4} \mathrm{~N}$ coordi- nation. On coordination with peroxide $\left(\mathrm{O}_{2}^{2-}\right)$, they form peroxo complexes where the axial (proximal) histidine moves to a basal position giving rise to a tetragonal $\left\{\mathrm{VO}\left(\mathrm{O}_{2}\right)(\mathrm{OH})(\mathrm{His})\right\}$ pyramid with the peroxo ligand occupying two equatorial positions in the symmetrical side-on manner. ${ }^{19}$ The peroxo form has also been structurally characterized for the fungal Curvularia inaequalis. ${ }^{20}$

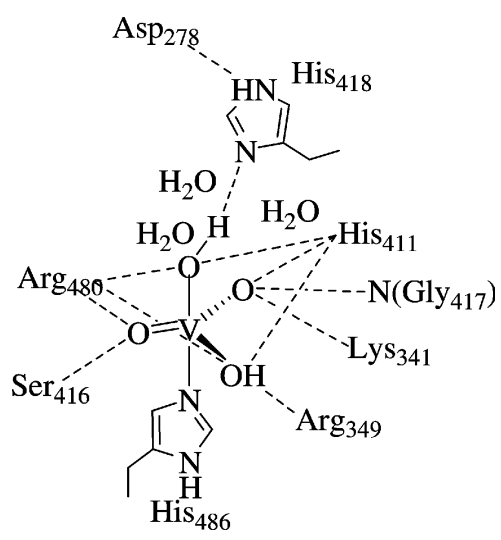

Figure 1. Active site structure of vanadate-dependent haloperoxidase from Ascophyllum nodosum. 
These enzymes catalyse the oxidation of halides $\left(\mathrm{X}^{-}\right)$to hypohalous acid (HOX) according to (1) below, using $\mathrm{H}_{2} \mathrm{O}_{2}$ as an oxidant followed by non-enzymatically halogenation of organic compounds. ${ }^{21,22}$

$$
\begin{aligned}
& \mathrm{X}^{-}+\mathrm{H}_{2} \mathrm{O}_{2}+\mathrm{H}^{+} \rightarrow \mathrm{HOX}+\mathrm{H}_{2} \mathrm{O}, \\
& \mathrm{X}^{-}=\mathrm{Cl}^{-}, \mathrm{Br}^{-} \text {and } \mathrm{I}^{-}, \\
& \mathrm{HOX}+\mathrm{RH} \rightarrow \mathrm{RX}+\mathrm{H}_{2} \mathrm{O},
\end{aligned}
$$

$\mathrm{RH}=$ organic substrate, $\mathrm{RX}=$ halogenated product .

Without a suitable organic substrate, the twoelectron oxidation of halide may result in production of singlet oxygen,

$$
\mathrm{HOX}+\mathrm{H}_{2} \mathrm{O}_{2} \rightarrow{ }^{1} \mathrm{O}_{2}+\mathrm{X}^{-}+\mathrm{H}^{+} .
$$

They also oxidize (prochiral) sulphide to (chiral) sulphoxide, as ${ }^{23,24}$

$$
\mathrm{RSR}^{\prime}+\mathrm{H}_{2} \mathrm{O}_{2} \rightarrow \mathrm{RS}(\mathrm{O}) \mathrm{R}^{\prime}+\mathrm{H}_{2} \mathrm{O} .
$$

Intermediate species having $\left\{\mathrm{VO}\left(\mathrm{H}_{2} \mathrm{O}\right)\right\},\left\{\mathrm{VO}_{2}\right\}$, $\{\mathrm{VO}(\mathrm{OH})\}$ and $\left\{\mathrm{VO}\left(\mathrm{O}_{2}\right)\right\}$ cores have been postulated during catalytic turnover. The stability of vanadium(V) complexes under aerobic conditions has allowed the design of structural and/or functional models for the haloperoxidases and to isolate or generate species with the above group in solution. ${ }^{25}$ In this report, we briefly discuss our recent efforts in designing structural models for haloperoxidases. Reactivity of the resulting complexes with various substrates has also been carried out to explore the other aspects of these complexes.

\section{Structural models of haloperoxidases}

\subsection{Complexes with dianionic ONO donor ligands}

The dioxovanadium $(\mathrm{V})$ complexes $\left[\mathrm{K}\left(\mathrm{H}_{2} \mathrm{O}\right)\right]\left[\mathrm{VO}_{2}\right.$ (sal-inh) $]\left(\mathrm{H}_{2} \mathrm{~L}=\mathbf{I}, \mathrm{R}=\mathrm{H}\right)$ and $\left[\mathrm{K}\left(\mathrm{H}_{2} \mathrm{O}\right)\right]\left[\mathrm{VO}_{2}(\mathrm{Cl}-\right.$ sal-inh)] $\left(\mathrm{H}_{2} \mathrm{~L}=\mathrm{I}, \mathrm{R}=\mathrm{Cl}\right)$ have been isolated by the reaction of potassium vanadate $(\mathrm{V})$, prepared in situ by dissolving $\mathrm{V}_{2} \mathrm{O}_{5}$ in aqueous $\mathrm{KOH}$, and potassium salt of ligands $\mathbf{I}$ at $\mathrm{pH} \approx 7 \cdot 5$. The final $\mathrm{pH}$ of the reaction mixture plays an important role in that a decrease in $\mathrm{pH}$ (to $\approx 6 \cdot 5$ ) causes the formation of oxobridged binuclear complexes $\left[\{\mathrm{VO}(\mathrm{sal}-\mathrm{inh})\}_{2} \mu-\mathrm{O}\right]$ and $\left[\{\mathrm{VO}(\mathrm{Cl} \text {-sal-inh })\}_{2} \mu-\mathrm{O}\right]$ along with the respective anionic species. These anionic and neutral complexes can be separated by fractional crystallization where binuclear complex crystallizes out first.<smiles>[R]c1ccc(O)c(/C=N/NC(=O)c2ccncc2)c1</smiles>

I $\mathrm{R}=\mathrm{H}: \mathrm{H}_{2}$ sal-inh $\mathrm{R}=\mathrm{Cl}: \mathrm{H}_{2} \mathrm{Cl}$-sal-inh

Similarly, reaction of $\mathrm{NH}_{4}\left[\mathrm{VO}_{3}\right]$ and the sodium salt of $\mathrm{H}_{2}$ sal-inh results in the formation of the corresponding ammonium salt $\mathrm{NH}_{4}\left[\mathrm{VO}_{2}(\right.$ sal-inh $\left.)\left(\mathrm{H}_{2} \mathrm{O}\right)\right]$ and $\left[\{\mathrm{VO}(\mathrm{sal}-\mathrm{inh})\}_{2} \mu-\mathrm{O}\right]$. The binuclear complexes have also been synthesized by allowing equimolar amounts of $\left[\mathrm{VO}(\mathrm{acac})_{2}\right]$ and ligand to react in acetone, followed by aerial oxidation as shown in scheme 1 . Intermediate oxovanadium(IV) complexes [VO(salinh $\left.)\left(\mathrm{H}_{2} \mathrm{O}\right)\right]$ and $\left[\mathrm{VO}(\mathrm{Cl}\right.$-sal-inh $\left.)\left(\mathrm{H}_{2} \mathrm{O}\right)\right]$ can also be isolated as a stable solid. ${ }^{26}$

The existence of two sharp bands in the 900$950 \mathrm{~cm}^{-1}$ in dioxovanadium(V) complexes suggests a cis- $\mathrm{VO}_{2}$ arrangement. In binuclear complexes, one sharp band arises at $\approx 960 \mathrm{~cm}^{-1}$, assignable to $v(\mathrm{~V}=\mathrm{O})$, and a broad band is observed at $\approx 860 \mathrm{~cm}^{-1}$ due to $v[\mathrm{~V}-(\mu-\mathrm{O})-\mathrm{V}]$. All the complexes display an intense to medium electronic spectral band at 403$410 \mathrm{~nm}$ which is assigned to ligand-to-metal charge transfer (LMCT) transition from phenolate oxygen atom to an empty $d$-orbital of the vanadium atom.

${ }^{51} \mathrm{~V}$ NMR spectroscopy has been proved to be an important technique to investigate interaction of va-

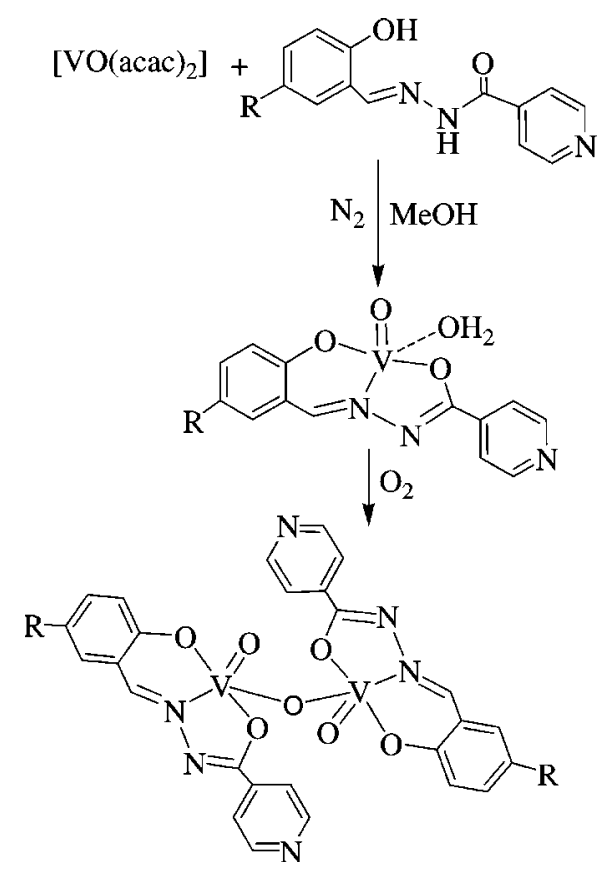

Scheme 1. 
nadium(V) with organic ligands. The dioxovana$\operatorname{dium}(\mathrm{V})$ complexes show one strong resonance between -539 and $-550 \mathrm{ppm}$ in DMSO- $d_{6}$ due to coordination of mixed $\mathrm{O} / \mathrm{N}$ donor ligands. However, owing to the quadrupolar interaction (for ${ }^{51} \mathrm{~V}$ nucleus: nuclear $\operatorname{spin}=7 / 2$, quadrupole moment $=-0.05 \times$ $10^{-28} \mathrm{~m}^{2}$ ), the resonances are somewhat broadened; the line widths at half-height are approximately $200 \mathrm{~Hz}$, which is still relatively narrow in ${ }^{51} \mathrm{~V}$ NMR spectroscopy. ${ }^{27}$

Anionic and neutral $\mu$-oxo binuclear complexes of the types $\left[\mathrm{VO}_{2} \mathrm{~L}\right]^{-}$and $\left[(\mathrm{VOL})_{2} \mu-\mathrm{O}\right] \quad\left(\mathrm{H}_{2} \mathrm{~L}=\right.$ ligands) with ligands II ( $\mathrm{H}_{2} \mathrm{sal}$-nah) and III $\left(\mathrm{H}_{2} \mathrm{sal}\right.$ fah) have also been isolated similarly as reported above. ${ }^{28}$<smiles>O=C(N/N=C/c1ccccc1O)c1cccnc1</smiles>

II: $\mathrm{H}_{2}$ sal-nah

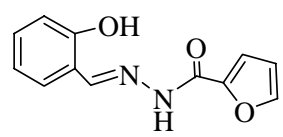

III: $\mathrm{H}_{2}$ sal-fah

Neutral complexes $\left[\{\mathrm{VO}(\text { sal-nah })\}_{2} \mu-\mathrm{O}\right]$ and $\left[\{\mathrm{VO}(\mathrm{sal}-\mathrm{fah})\}_{2} \mu-\mathrm{O}\right]$ are stable in the solid state, but undergo deoxygenation slowly in methanol to give $[\mathrm{VO}(\mathrm{OMe})(\mathrm{MeOH})($ sal-nah)] and $[\mathrm{VO}(\mathrm{OMe})$ $(\mathrm{MeOH})(\mathrm{sal}-\mathrm{fah})]$ respectively. Molecular structures of these oxo-methoxo complexes are presented in figure 2 . The coordination geometry around vanadium can be described as tetragonal bipyramidal, with the doubly bonded oxygen and methanol in axial

(a)

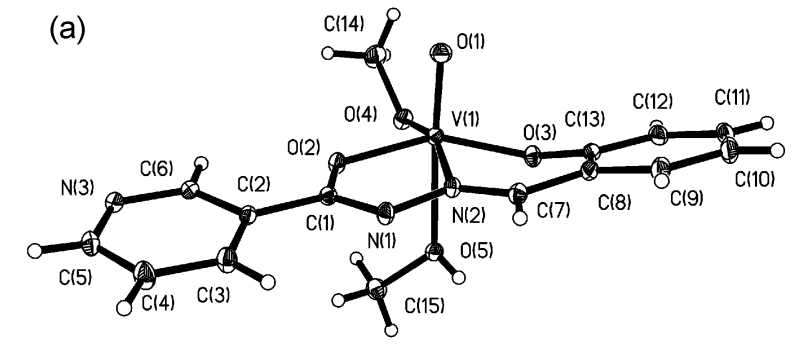

(1)

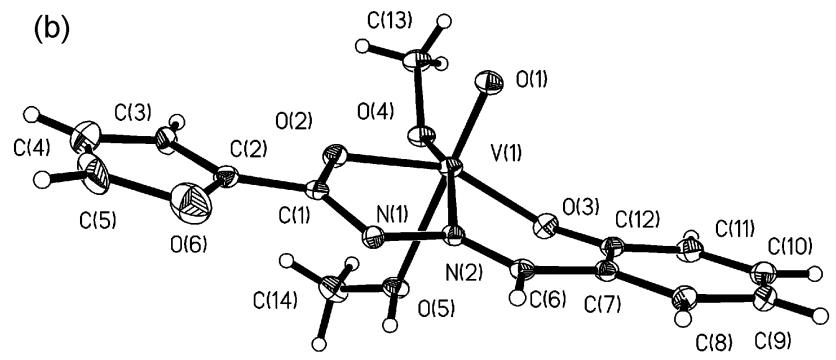

Figure 2. ORTEP plot (at 50\% probability level) of $[\mathrm{VO}(\mathrm{OMe})(\mathrm{MeOH})($ sal-nah)] (a) and $[\mathrm{VO}(\mathrm{OMe})(\mathrm{MeOH})$ (sal-fah)] (b). positions. The $\mathrm{O}=\mathrm{V}-\mathrm{O}$ (methanol) axis is almost linear; the angle at vanadium is $175.39(5)^{\circ}$ in [VO $(\mathrm{OMe})(\mathrm{MeOH})(\mathrm{sal}-\mathrm{nah})]$ and $173 \cdot 4(2)^{\circ}$ in [VO $(\mathrm{OMe})(\mathrm{MeOH})(\mathrm{sal}-\mathrm{fah})]$. Owing to the trans influence of the oxo group, the vanadium-methanol distance $\{d(\mathrm{~V}-\mathrm{O} 5)$ of $2 \cdot 2514(10) \AA$ in $[\mathrm{VO}(\mathrm{OMe})$ $(\mathrm{MeOH})($ sal-nah)] and 2.3081(15) $\AA$ in [VO(OMe) $(\mathrm{MeOH})(\mathrm{sal}-\mathrm{fah})]\}$ is considerably elongated, making the methanol a weakly coordinated ligand.

Aqueous solutions of $\left[\mathrm{VO}_{2} \text { (sal-nah) }\right]^{-}$and $\left[\mathrm{VO}_{2}\right.$ (sal-fah) $]^{-}$react with $\mathrm{HClO}_{4}$ or $\mathrm{HCl}$ to yield the neutral complexes $\left[\mathrm{VO}_{2}(\mathrm{Hsal}-\mathrm{nah})\right]$ and $\left[\mathrm{VO}_{2}(\mathrm{Hsal}-\right.$ fah)] respectively, in which one of the nitrogens of the $-\mathrm{N}=\mathrm{N}-$ group is protonated. Isolation and structural characterization of such complexes, e.g. $\left[\mathrm{VO}_{2}(\mathrm{Hsal}-\mathrm{bhz})\right]$, has been reported by Plass et al. ${ }^{29}$ Slow crystallization of $\left[\mathrm{VO}_{2}(\mathrm{Hsal}-\mathrm{nah})\right]$ and $\left[\mathrm{VO}_{2}\right.$ (Hsal-fah)] from excess methanol causes the removal of the proton from the NH group and conversion to the methoxo-oxovanadium $(\mathrm{V})$ complexes as mentioned above. The formation of the methoxooxovanadium $(\mathrm{V})$ complexes from the corresponding neutral mono- or $\mu$-oxo binuclear oxovanadium(V) complexes in methanol is of interest in the context of vanadium complexes used as oxo-transfer agents both in catalytic and stoichiometric oxygenation reactions. ${ }^{30}$ Scheme 2 presents the whole synthetic procedures.

Reaction between equimolar amounts of [VO (acac $)_{2}$ ] and ligands IV $\left(\mathrm{H}_{2}\right.$ pydx-inh $), \mathbf{V}\left(\mathrm{H}_{2}\right.$ pydxnah) and VI $\left(\mathrm{H}_{2}\right.$ pydx-bhz) in dry refluxing methanol gave oxovanadium(IV) complexes from which neutral dioxovanadium(V) complexes $\left[\mathrm{VO}_{2}(\mathrm{Hpydx}\right.$-inh $\left.)\right]$, $\left[\mathrm{VO}_{2}(\mathrm{Hpydx}-\mathrm{nah})\right]$ and $\left[\mathrm{VO}_{2}(\mathrm{Hpydx}-\mathrm{bhz})\right]$ have been isolated on aerial oxidation. ${ }^{31}$

In these complexes, the nitrogen in pyridine is protonated. However, the NH proton signal was not observed in the ${ }^{1} \mathrm{H}$ NMR spectra of the complexes due

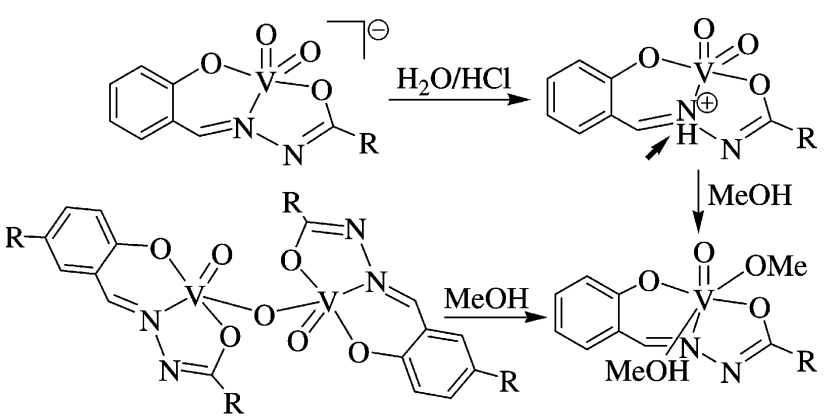

$\mathrm{R}=3$-pyridyl, 2-furyl

Scheme 2. 


$$
\text { (N) }
$$

IV: $\mathrm{H}_{2}$ pydx-inh

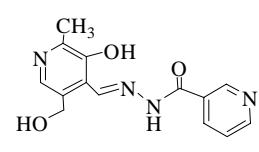

V: $\mathrm{H}_{2}$ pydx-nah

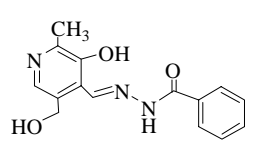

VI: $\mathrm{H}_{2}$ pydx-bhz to its labile nature. These neutral complexes can also be obtained by the reaction of potassium vanadate with the solution of potassium salts of ligands and adjusting the $\mathrm{pH}$ of the reaction mixture to $6 \cdot 5$. However, adjustment of the $\mathrm{pH}$ of these solutions to 7.5 resulted in the formation of a mixture of neutral dioxovanadium(V) (as noted above) in minor yield and anionic dioxovanadium $(\mathrm{V})$ complexes $\left[\mathrm{K}\left(\mathrm{H}_{2} \mathrm{O}\right)_{3}\right]\left[\mathrm{VO}_{2}\right.$ (pydx-inh) $], \quad\left[\mathrm{K}\left(\mathrm{H}_{2} \mathrm{O}\right)_{2}\right]\left[\mathrm{VO}_{2}\right.$ (pydxnah)] and $\left[\mathrm{K}\left(\mathrm{H}_{2} \mathrm{O}\right)_{2}\right]\left[\mathrm{VO}_{2}\right.$ (pydx-bhz)], in major yield. Thus, the final $\mathrm{pH}$ of the reaction mixture plays an important role. It is interesting to note that no binuclear complex formation was observed in this system. Scheme 3 presents the synthetic procedure.

These two types of complexes can be separated by fractional crystallization from methanol where the neutral complex crystallizes first. At ${ }^{51} \mathrm{~V}$ NMR scale, both types of complexes have close similarity; $\left[\mathrm{VO}_{2}(\mathrm{Hpydx}-\mathrm{bhz})\right]$ exhibits a sharp signal at -535.7 ppm while $\left[\mathrm{K}\left(\mathrm{H}_{2} \mathrm{O}\right)_{2}\right]\left[\mathrm{VO}_{2}(\right.$ pydx-bhz $\left.)\right]$ exhibits this signal at $-534 \cdot 2 \mathrm{ppm}$ in DMSO- $d_{6}$.

The crystal and molecular structure of complex $\left[\mathrm{K}\left(\mathrm{H}_{2} \mathrm{O}\right)_{3}\right]\left[\mathrm{VO}_{2}\right.$ (pydx-inh)] has been solved by single-crystal X-ray diffraction and is presented in figure 3 . The geometry of the vanadium complex can be described in terms of a tetragonal pyramid, distorted towards a trigonal bipyramid. The $\tau$ value $[\{\angle(\mathrm{O} 3-$ $\mathrm{V}-\mathrm{O} 4)-\angle(\mathrm{O} 2-\mathrm{V}-\mathrm{N} 3)\} / 60$ ] of $0 \cdot 23$ ( $\tau=0$ vs 1 for ideal tetragonal vs trigonal arrangements) quantifies this distortion. This is a common situation encountered with penta-coordinated oxovanadium complexes. The cis-dioxovanadium unit is coordinated through the phenolate oxygen $\mathrm{O} 3$ of the isonicotinic acid hy-

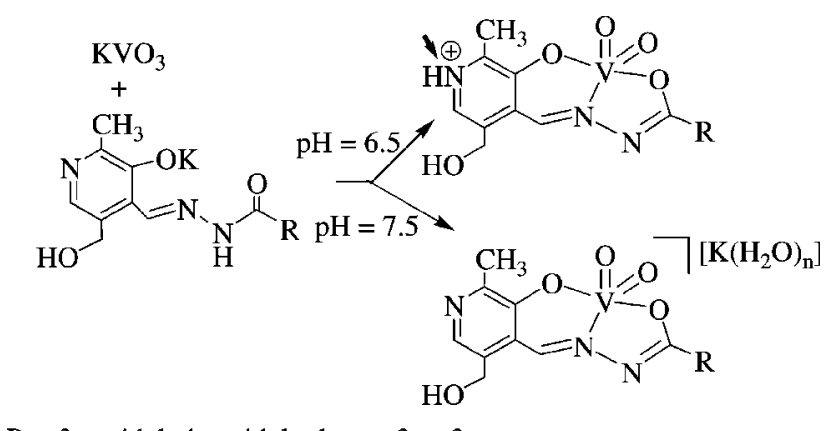

$\mathrm{R}=3$-pyridyl, 4-pyridyl, ph; $\mathrm{n}=2$ or 3 drazone. Together with the doubly bonded O2, bridging to potassium, these functions form the tetragonal plane. The $\mathrm{K}^{+}$ion is coordinated to four water molecules (two of which bridge to a neighbouring $\mathrm{K}^{+}$), the pyridine nitrogen of an isonicotinic moiety, the equatorial oxo group of the $\mathrm{VO}_{2}^{+}$fragment, and the alcoholic group of the pyridoxal moiety, which links to the three-dimensional network.

\subsection{Complexes with monobasic ONN donor ligand}

Reaction between equimolar amounts of [VO $(\mathrm{acac})_{2}$ ] and ligands VII (Hacpy-inh) and VIII (Hacpy-bhz) in dry, refluxing methanol yielded oxovanadium(IV) complexes [VO(acac)(acpy-inh)] and $[\mathrm{VO}(\mathrm{acac})(\mathrm{acpy}-\mathrm{bhz})]$ respectively. These complexes slowly oxidized in methanol to give the corresponding dioxovanadium(V) complexes. A few drops of water facilitate this oxidation. Scheme 4 represents the synthetic procedures.

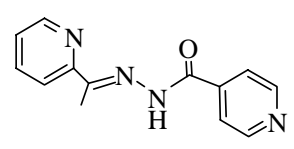

VII: Hacpy-inh

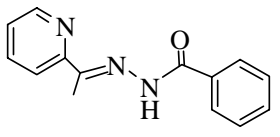

VIII: Hacpy-bhz
Coordination geometry around vanadium in $\left[\mathrm{VO}_{2}\right.$ (acpy-inh)] and $\left[\mathrm{VO}_{2}\right.$ (acpy-bhz)] can be described as distorted square-pyramidal where one of the doubly bonded oxo groups, the pyridine- $\mathrm{N}$, imine- $\mathrm{N}$ and the amide- $\mathrm{O}$ of the monobasic tridentate ligands, form the base (figure 4). ${ }^{32} \mathrm{~V}=\mathrm{O}$ distances of 1.615 and $1.618 \AA$ are typical of non-hydrogen-bonded $\mathrm{V}=\mathrm{O}$ groups. There are substantial distortions towards a trigonal bipyramid, quantified by $\tau$ parameters of $0 \cdot 37$.

Ligands IX (Hacpy-nah) and X (Hacpy-fah) are similar to VII and VIII, but give binuclear com-

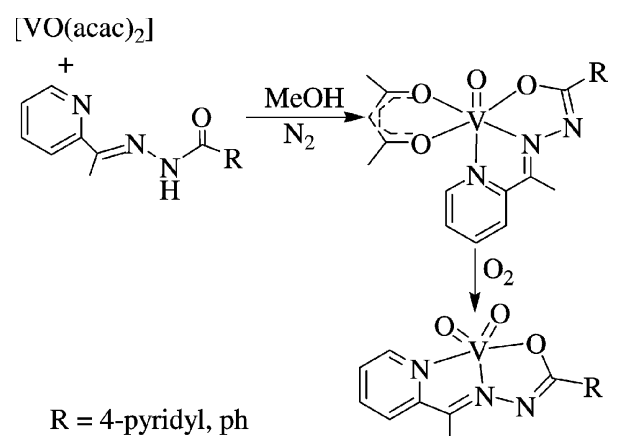

Scheme 4.

Scheme 3. 
plexes $\left[\{\mathrm{VO}(\text { acpy-nah })\}_{2}(\mu-\mathrm{O})_{2}\right]$ and $[\{\mathrm{VO}($ acpyfah) $\}_{2}(\mu-\mathrm{O})_{2}$ ] on oxidation of the methanolic solutions of their corresponding oxovanadium(IV) complexes [VO(acac)(acpy-nah)] and [VO(acac)(acpyfah)]. ${ }^{33}$ Deflon et $a l^{34}$ have isolated the binuclear complex $\left[\{\mathrm{VO}(\text { acpy-fah })\}_{2}(\mu-\mathrm{O})_{2}\right]$ along with the non-separable mononuclear $\left[\mathrm{VO}_{2}(\mathrm{acpy}-\mathrm{fah})\right]$ in minor amounts. However, the latter could only be characterized by single-crystal X-ray method.<smiles>C/C(=N\NC(=O)c1cccnc1)c1ccccn1</smiles>

IX: Hacpy-nah<smiles>Cc1ccccn1</smiles>

X: Hacpy-fah
The binuclear complexes exhibit one strong resonance at $\approx-509.3 \mathrm{ppm}$. In these complexes the two vanadium atoms, with distorted octahedral coordination, are bridged symmetrically through two oxo-

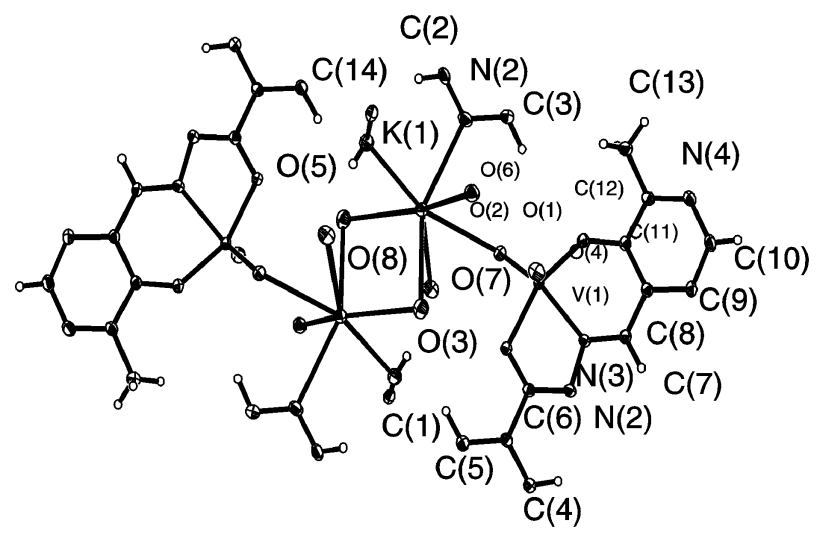

Figure 3. ORTEP plot (at $30 \%$ probability level) of $\left[\mathrm{K}\left(\mathrm{H}_{2} \mathrm{O}\right)_{3}\right]\left[\mathrm{VO}_{2}(\right.$ pydx-inh $\left.)\right]$.

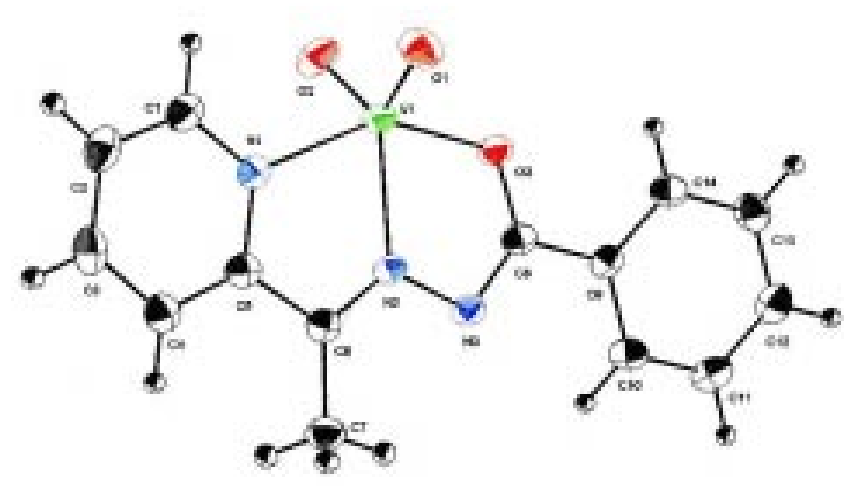

Figure 4. ORTEP plot with $35 \%$ probability level of $\left[\mathrm{VO}_{2}(\right.$ acpy-bhz $\left.)\right]$. ligands. The vanadium centre in [\{ $\mathrm{VO}($ acpynah) $\}_{2}(\mu-\mathrm{O})_{2}$ ] is in the plane surrounded by the three coordinating ligand functions $(\mathrm{N} 1, \mathrm{~N} 2, \mathrm{O} 3)$ and the symmetry-related bridging oxygen $\mathrm{O} 2 \mathrm{~A}$ (figure 5).

\section{Reactivity of model complexes}

\subsection{Reactivity with $\mathrm{H}_{2} \mathrm{O}_{2}$}

As mentioned in $\S 1$, haloperoxidases coordinate with peroxide to give $\eta^{2}$-peroxo species. Such species have also been either isolated or generated in solution and characterized by spectroscopic study. Thus, treatment of a methanolic solution of $\left[\mathrm{K}\left(\mathrm{H}_{2} \mathrm{O}\right)\right]$ $\left[\mathrm{VO}_{2}\right.$ (sal-inh)] with aqueous $30 \% \mathrm{H}_{2} \mathrm{O}_{2}$ yields the peroxo complex $\mathrm{K}\left[\mathrm{VO}\left(\mathrm{O}_{2}\right)(\mathrm{sal}-\mathrm{inh})\left(\mathrm{H}_{2} \mathrm{O}\right)\right]$. Complex $\mathrm{K}\left[\mathrm{VO}\left(\mathrm{O}_{2}\right)(\mathrm{Cl}\right.$-sal-inh $\left.)\left(\mathrm{H}_{2} \mathrm{O}\right)\right]$ has also been isolated similarly. These complexes show three IR active vibrational modes associated with the $\left[\mathrm{V}\left(\mathrm{O}_{2}\right)\right]^{2+}$ moiety, namely the symmetric $\mathrm{V}\left(\mathrm{O}_{2}\right)$ stretch $\left(v_{2}\right)$ at $\approx 580 \mathrm{~cm}^{-1}$, the antisymmetric $\mathrm{V}\left(\mathrm{O}_{2}\right)$ stretch $\left(v_{3}\right)$ at $\approx 740 \mathrm{~cm}^{-1}$, and the $\mathrm{O}-\mathrm{O}\left(v_{1}\right)$ stretch at $\approx 895 \mathrm{~cm}^{-1}$, characteristic of $\eta^{2}$-coordination of the peroxo group. In addition, they display the $v(\mathrm{~V}=\mathrm{O})$ mode at $\approx 950 \mathrm{~cm}^{-1}$. These complexes are unstable and lose oxygen even at ambient temperature within a day. Formation of peroxo complexes in methanol by the treatment of $5 \mathrm{ml}$ of $\approx 10^{-4} \mathrm{M}$ solutions of [\{ $\mathrm{VO}$ (salinh) $\}_{2} \mu$-O] with aqueous $30 \% \mathrm{H}_{2} \mathrm{O}_{2}$ dissolved in methanol has been established by electronic absorption spectroscopy. ${ }^{26}$ Thus, the band for $[\{\mathrm{VO}($ sal-

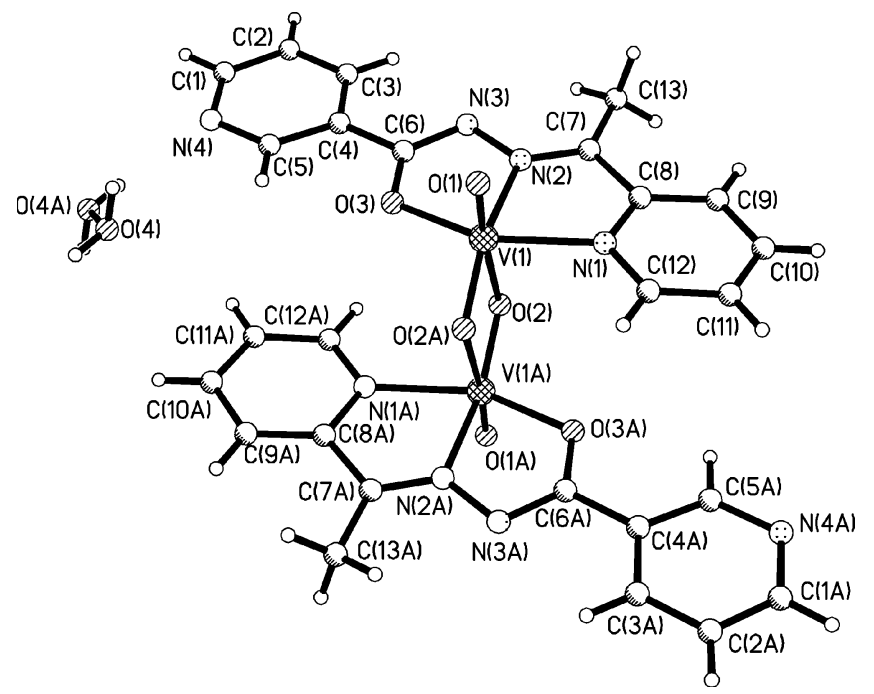

Figure 5. ORTEP plot $(30 \%$ probability level) of $\left[\{\mathrm{VO}(\text { acpy-nah })\}_{2}(\mu-\mathrm{O})_{2}\right] 1 \cdot 5 \mathrm{H}_{2} \mathrm{O}$. 
inh) $\left.\}_{2} \mu-\mathrm{O}\right]$ at $402 \cdot 5 \mathrm{~nm}$ shifts to $412 \mathrm{~nm}$ along with an increase in intensity. The new bands remain constant for several hours at approximately $10^{\circ} \mathrm{C}$. The amount of peroxo complex formed depends upon the amount of $\mathrm{H}_{2} \mathrm{O}_{2}$ added. The final spectral pattern is similar to that obtained for the isolated peroxo complex $\left[\mathrm{VO}\left(\mathrm{O}_{2}\right)(\mathrm{sal}-\mathrm{inh})\left(\mathrm{H}_{2} \mathrm{O}\right)\right]^{-}$. Similar spectral patterns are also observed for $\left[\mathrm{K}\left(\mathrm{H}_{2} \mathrm{O}\right)\right]\left[\mathrm{VO}_{2}\right.$ (sal-nah)] and $\left[\mathrm{K}\left(\mathrm{H}_{2} \mathrm{O}\right)\right]\left[\mathrm{VO}_{2}\right.$ (sal-fah)]. The ${ }^{51} \mathrm{~V}$ NMR spectrum of $\left[\mathrm{K}\left(\mathrm{H}_{2} \mathrm{O}\right)\right]\left[\mathrm{VO}_{2}(\mathrm{sal}-\mathrm{fah})\right]$ in $\mathrm{DMSO} / \mathrm{H}_{2} \mathrm{O}$ plus a small amount of $\mathrm{HClO}_{4}$ and $\mathrm{H}_{2} \mathrm{O}_{2}$, i.e. under conditions where the peroxo complexes should form and be fairly stable, resulted in the appearance of an additional peak at $-575 \mathrm{ppm}$ along with the original signal at $-538 \mathrm{ppm} .{ }^{28}$ The signal at $-575 \mathrm{ppm}$ reflects the presence of an oxomonoperoxo species. The peroxo ligand usually gives rise to an upfield shift of 40$60 \mathrm{ppm}$ with respect to the parent dioxovanadium $(\mathrm{V})$ complex.

Reaction of potassium vanadate with aqueous $30 \% \mathrm{H}_{2} \mathrm{O}_{2}$ in presence of ligand $\mathrm{H}_{2}$ pydx-bhz (VI) also resulted in the formation of stable peroxo complex $\mathrm{K}\left[\mathrm{VO}\left(\mathrm{O}_{2}\right)(\mathrm{pydx}-\mathrm{bhz})\right]$. Its formation in solution has also been established by electronic absorption spectroscopy (figure 6) by treating $\left[\mathrm{VO}_{2}(\text { pydx-bhz) }]^{-}\right.$ with $\mathrm{H}_{2} \mathrm{O}_{2}$ in methanol. The band for $\left[\mathrm{VO}_{2}(\mathrm{pydx}-\right.$ bhz)] $]^{-}$at $404.5 \mathrm{~nm}$ shifts to $424 \mathrm{~nm}$ along with increase in intensity on dropwise addition of $\mathrm{H}_{2} \mathrm{O}_{2}$, while the band at $329 \mathrm{~nm}$ shifts marginally to

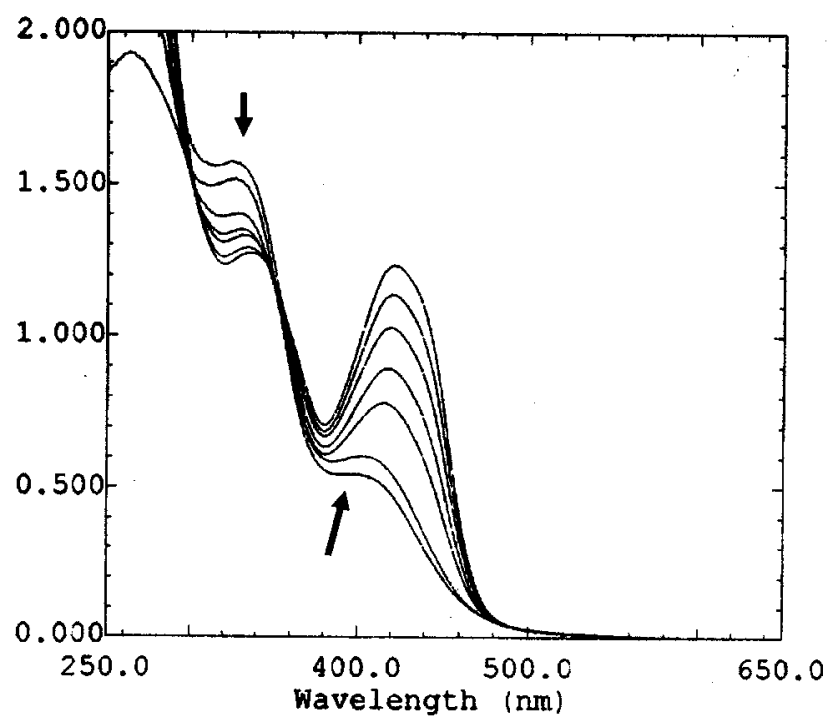

Figure 6. Titration of $\left[\mathrm{K}\left(\mathrm{H}_{2} \mathrm{O}\right)_{2}\right]\left[\mathrm{VO}_{2}(\mathrm{pydx}-\mathrm{bhz})\right]$ with $30 \% \mathrm{H}_{2} \mathrm{O}_{2}$; the spectra were recorded after successive addition of 2-drop portions of $\mathrm{H}_{2} \mathrm{O}_{2}$ to $10 \mathrm{ml}$ of $\mathrm{a} \approx 10^{-4} \mathrm{M}$ solution of complex in $\mathrm{MeOH}$.
$333 \mathrm{~nm}$ with partial reduction in intensity. The final spectrum is again similar to that obtained for the isolated peroxo complex $\mathrm{K}\left[\mathrm{VO}\left(\mathrm{O}_{2}\right)\left(\right.\right.$ pydx-bhz) . $^{31}$

\subsection{Reactivity with $\mathrm{HCl}$}

For the catalytic activity of vanadate-dependent haloperoxidases, the presence of a coordinated hydroxo ligand has been proposed on the basis of kinetic investigations. The generation of oxo-hydroxo species has been accomplished for $[\{\mathrm{VO}(\mathrm{sal}-$ inh) $\left.\left.\}_{2} \mu-\mathrm{O}\right\}\right]$ on reaction with $\mathrm{HCl}$. Addition of $\mathrm{HCl}-$ saturated methanol to the methanolic solution of $\left.\left[\{\mathrm{VO}(\text { sal-inh })\}_{2} \mu-\mathrm{O}\right\}\right]$ results in a colour change from orange-red to dark red with a gradual shift of the bands at 322 and $402.5 \mathrm{~nm}$ to 341 and $425 \mathrm{~nm}$ respectively. Similar behaviour is also observed for $\left.\left[\{\mathrm{VO}(\mathrm{Cl}-\mathrm{sal}-\mathrm{inh})\}_{2} \mu-\mathrm{O}\right\}\right]$ where the bands at 321.5 and $408.5 \mathrm{~nm}$ gradually shift to 337 and $428 \mathrm{~nm}$ on acidification. For complex $\left[\mathrm{K}\left(\mathrm{H}_{2} \mathrm{O}\right)\right]\left[\mathrm{VO}_{2}\right.$ (sal-fah)], the UV bands at 282.5, 301 and $324 \mathrm{~nm}$ finally merge into two bands at 300 and $318 \mathrm{~nm}$, while a shoulder appears at $\approx 290 \mathrm{~nm}$. These results have been interpreted in terms of the formation of oxo-hydroxo complexes of composition [ $\mathrm{VO}(\mathrm{OH})(\mathrm{HL})]$ via intermediate $\left[\mathrm{VO}_{2}(\mathrm{HL})\right]$ where one of the $=\mathrm{N}-\mathrm{N}=$ nitrogens is the site of protonation. As mentioned in \$2.1, the structurally characterized complex [VO(Hsalbhz)] has protonated hydrazone nitrogen and is obtained on treatment of the corresponding anionic dioxo complex with $\mathrm{HCl}^{29}$

Complex $\left[\mathrm{K}\left(\mathrm{H}_{2} \mathrm{O}\right)_{2}\right]\left[\mathrm{VO}_{2}(\mathrm{pydx}-\mathrm{bhz})\right]$, provides results as shown in figure 7 and is again similar to those observed above. Corresponding results have also been obtained with $\mathrm{HClO}_{4}$ (dissolved in a minimum amount of methanol) and added dropwise to a methanolic solution of $\left[\mathrm{K}\left(\mathrm{H}_{2} \mathrm{O}\right)_{2}\right]\left[\mathrm{VO}_{2}(\mathrm{pydx}-\mathrm{bhz})\right]$. These results have been interpreted in terms of the formation of an oxo-hydroxo complex of composition $\left[\mathrm{VO}(\mathrm{OH})\left(\mathrm{H}_{2} \text { pydx-bhz }\right)\right]^{2+}$ also but via $\left[\mathrm{VO}_{2}(\mathrm{Hpydx}-\right.$ bhz $)]$ and $\left[\mathrm{VO}_{2}\left(\mathrm{H}_{2} \text { pydx-bhz }\right)\right]^{+}$on acidification as shown in scheme 5 . The formation of the intermediate species, protonated at the pyridine- $\mathrm{N}$, viz. $\left[\mathrm{VO}_{2}\right.$ (Hpydx-bhz)], is based on the fact that electronic absorption spectrum of a solution of $\left[\mathrm{K}\left(\mathrm{H}_{2} \mathrm{O}\right)_{2}\right]$ $\left[\mathrm{VO}_{2}(\text { pydx-bhz })\right]^{-} \stackrel{\mathrm{H}^{+}}{\rightarrow}\left[\mathrm{VO}_{2}(\mathrm{Hpydx}-\mathrm{bhz})\right] \stackrel{\mathrm{H}^{+}}{\rightarrow}\left[\mathrm{VO}_{2}\left(\mathrm{H}_{2} \text { pydx-bhz }\right)\right]^{+}$ $\mathrm{H}^{+}$ $\rightarrow\left[\mathrm{VO}(\mathrm{OH})\left(\mathrm{H}_{2} \mathrm{pydx}-\mathrm{bhz}\right)\right]^{2+}$

Scheme 5. 
[ $\left.\mathrm{VO}_{2}(\mathrm{pydx}-\mathrm{bhz})\right]$ obtained after addition of 4 drops of $\mathrm{HCl}$ nearly matches the spectrum of the authentic complex $\left[\mathrm{VO}_{2}(\mathrm{Hpydx}-\mathrm{bhz})\right]$. The protonation of the $\mathrm{N}$ of the hydrazide moiety not involved in coordination is supplemented by a newly arising medium intensity band in the IR at $3205 \mathrm{~cm}^{-1}$ (free Schiff base: $\left.3210 \mathrm{~cm}^{-1}\right)$ on acidification of $\left[\mathrm{K}\left(\mathrm{H}_{2} \mathrm{O}\right)_{2}\right]\left[\mathrm{VO}_{2}(\mathrm{pydx}-\right.$ bhz)]. ${ }^{31}$

\subsection{Reactivity with noninnocent ligands}

The ligands catechol and benzohydroxamic acid belong to this category and generally bind to vanadium

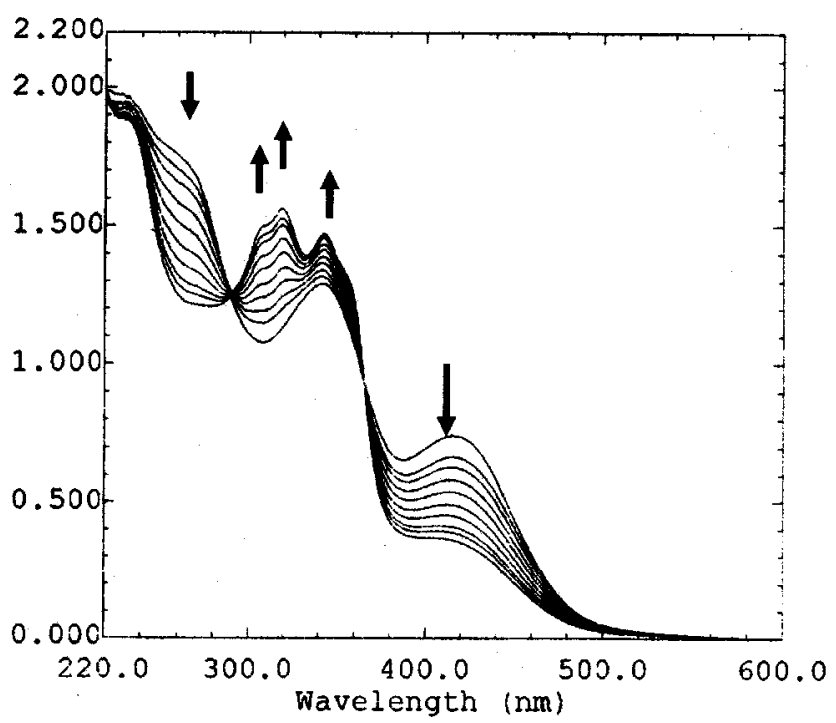

Figure 7. Titration of $\left[\mathrm{K}\left(\mathrm{H}_{2} \mathrm{O}\right)_{2}\right]\left[\mathrm{VO}_{2}(\mathrm{pydx}-\mathrm{bhz})\right]$ with a saturated solution of $\mathrm{HCl}$ in $\mathrm{MeOH}$; the spectra were recorded after addition of 2 drops portions $\mathrm{MeOH}-\mathrm{HCl}$ to $10 \mathrm{ml}$ of $\approx 10^{-4} \mathrm{M}$ solution of complex in $\mathrm{MeOH}$.

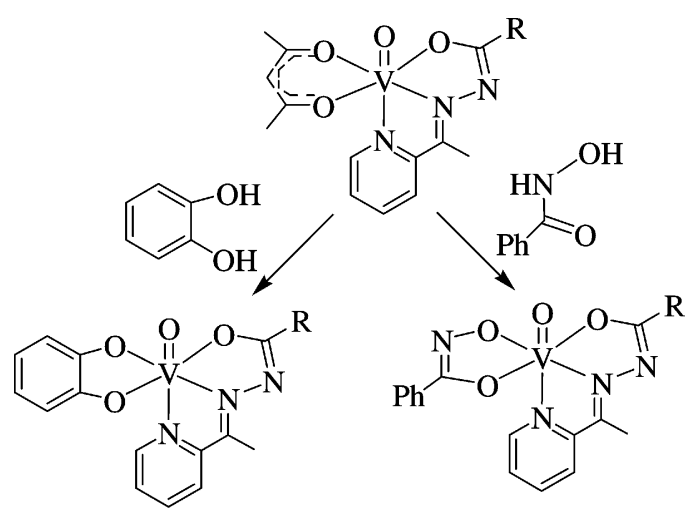

$\mathrm{R}=$ 3-pyridyl, 4-pyridyl, 2-furyl and ph.

Scheme 6. in high-valent state. The relevance of catecholatovanadium complexes in terms of their biological

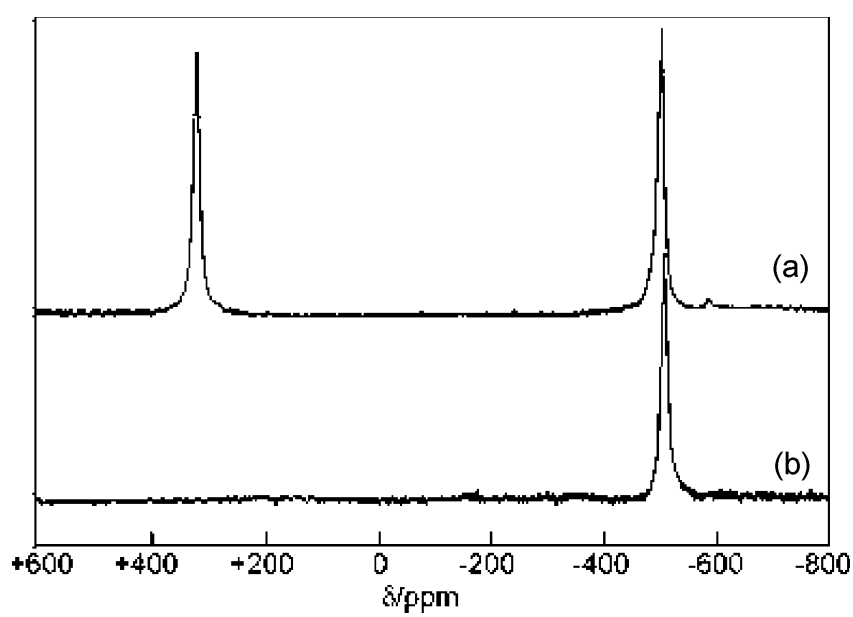

Figure 8. ${ }^{51} \mathrm{~V}$ NMR spectra of [VO(cat)(acpy-bhz)] (a) and $\left[\mathrm{VO}_{2}(\mathrm{acpy}-\mathrm{bhz})\right](\mathbf{b})$ recorded in DMSO-d $d_{6}$.

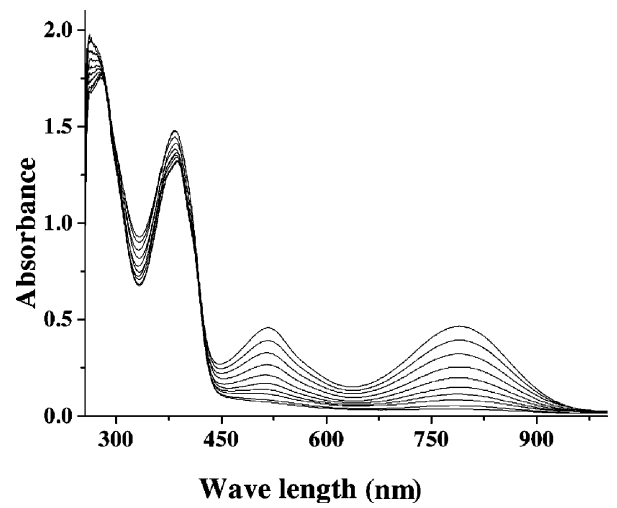

Figure 9. Decomposition of [VO(cat)(acpy-nah)] in $5 \mathrm{ml}$ of DMSO after the addition of two drops of water, as a function of time.

Table 1. ${ }^{51} \mathrm{~V}$ NMR spectra data.

\begin{tabular}{|c|c|c|}
\hline \multirow[b]{2}{*}{ Complex } & \multicolumn{2}{|c|}{ Chemical shift ( $\delta$ in ppm) } \\
\hline & Peak 1 & Peak 2 \\
\hline [VO(cat)(acpy-inh)] & $362 \cdot 4$ & $-506 \cdot 9,-585 \cdot 8$ \\
\hline [VO(bha)(acpy-inh)] & $70 \cdot 0$ & $-499 \cdot 3,-587 \cdot 7$ \\
\hline$\left[\mathrm{VO}_{2}(\right.$ acpy-inh $\left.)\right]$ & - & $-507 \cdot 1$ \\
\hline$[\mathrm{VO}(\mathrm{cat})(\mathrm{acpy}-\mathrm{bhz})]$ & $319 \cdot 1$ & $-507 \cdot 1,-589 \cdot 2$ \\
\hline [VO(bha)(acpy-bhz)] & $51 \cdot 2$ & $-506 \cdot 2,-590 \cdot 2$ \\
\hline$\left[\mathrm{VO}_{2}(\mathrm{acpy}-\mathrm{bhz})\right]$ & - & -507.8 \\
\hline [VO(cat)(acpy-nah)] & 343 & $-506 \cdot 9$ \\
\hline [VO(bha)(acpy-nah)] & $66 \cdot 5$ & $-502 \cdot 9$ \\
\hline$\left[\{\mathrm{VO}(\text { acpy-nah })\}_{2}(\mu-\mathrm{O})_{2}\right]$ & - & $-509 \cdot 3$ \\
\hline$[\mathrm{VO}(\mathrm{cat})(\mathrm{acpy}-\mathrm{fah})]$ & 340 & $-513 \cdot 5$ \\
\hline [VO(bha)(acpy-fah)] & $58 \cdot 3$ & $-505 \cdot 7$ \\
\hline$\left[\{\mathrm{VO}(\mathrm{acpy}-\mathrm{fah})\}_{2}(\mu-\mathrm{O})_{2}\right]$ & - & $-508 \cdot 2$ \\
\hline
\end{tabular}


significance arises from the role of tunichromes in reduction, stabilization and accumulation of vanadium by certain ascidians (sea squirts). The iron-binding sidophore desferrioxamine, which contains hydroxamate functions, also strongly binds to $\mathrm{VO}^{2+}$.

Reaction of catechol $\left(\mathrm{H}_{2} \mathrm{cat}\right)$ or benzohydroxamic acid $\left(\mathrm{H}_{2}\right.$ bha) with oxovanadium (IV) complex [VO (acac)(acpy-inh)] in methanol under aerobic conditions leads to the formation of the mixed ligand complexes [VO(cat)(acpy-inh)] and [VO(bha)(acpyinh)], respectively. ${ }^{32}$ During this reaction, oxidative replacement of the acetylacetonato group by catecholate or benzohydroxamate takes place as shown in scheme 6.

Similarly, oxovanadium(V) complexes [VO(cat)L] and $[\mathrm{VO}(\mathrm{bha}) \mathrm{L}]$, from the corresponding [VO (acac)L] (where HL = VIII, IX and $\mathbf{X}$ ), have been prepared. ${ }^{33}$ These complexes exhibit two resonances in their ${ }^{51} \mathrm{~V}$ NMR spectra (table 1) and their representative ${ }^{51} \mathrm{~V}$ NMR spectra of $\left[\mathrm{VO}_{2}\right.$ (acpy-bhz)] and $[\mathrm{VO}(\mathrm{cat})(\mathrm{acpy}-\mathrm{bhz})]$ are presented in figure 8. Lowfield signals between 319.1 and $362.4 \mathrm{ppm}$ in catacholate and between 51.2 and $70.0 \mathrm{ppm}$ in hydroxamate complexes (peak 1) are indicative of the catacholate/hydroxamate coordination and thus belong to the mixed-ligand complexes [ $\mathrm{VO}(\mathrm{cat}) \mathrm{L}]$ and [VO(bha)L] respectively. The second peaks in the range -499.3 to $-513.95 \mathrm{ppm}$ (peak 2) are due to their partial decomposition to the corresponding dioxovanadium $(\mathrm{V})$ complex. In some of the solutions, the presence of an additional minor resonance around $-590 \mathrm{ppm}$ matches with the corresponding oxoperoxo complexes.

The conversion of these mixed-chelate complexes into the $\left[\mathrm{VO}_{2}\right]^{+}$(peak 2) species with the loss of the bidentate catecholate (2-) and benzohydroxamate (2-) in DMSO was also establish by electronic absorption studies. In dry DMSO, conversion is rather slow and requires about $24 \mathrm{~h}$, while the addition of a few drops of water facilitates conversion. During this period, a gradual loss in intensity of the LMCT band(s) belonging to coordinated catecholate or benzohydroxamate is observed which finally disappears (figure 9).

\section{Conclusions}

At the active sites of vanadate-dependent haloperoxidases, vanadate has a trigonal-bipyramidal (native form) structure with $\mathrm{O}_{4} \mathrm{~N}$ coordination environment. Complexes reported in the present study partly model haloperoxidases. Intermediate species with
$\left\{\mathrm{VO}\left(\mathrm{H}_{2} \mathrm{O}\right)\right\},\left\{\mathrm{VO}_{2}\right\},\{\mathrm{VO}(\mathrm{OH})\}$ and $\left\{\mathrm{VO}\left(\mathrm{O}_{2}\right)\right\}$, as postulated during catalytic turnover, have also been either isolated or generated in solution and characterized. Reactivity of the model complexes with various substrates, isolation of the resulting complexes, their characterization and stability in solution, has been studied.

\section{Acknowledgements}

Financial assistance from the Department of Science and Technology, New Delhi and the Council of Scientific and Industrial Research, New Delhi is gratefully acknowledged.

\section{References}

1. Pecoraro V L, Slebodnick C and Hamstra B 1998 Vanadium complexes: Chemistry, biochemistry and theraeutic applications (ACS Symposium Series) (eds) D C Crans and A S Tracy (Washington, DC: Am. Chem. Soc.) ch. 12

2. Rehder D 2003 Inorg. Chem. Commun. 6604

3. Sakurai H, Kojima Y, Yoshikawa Y, Kawabe K and Yasui H 2002 Coord. Chem. Rev. 336187

4. Thompson K H, McNeill J H and Orvig C 1999 Chem. Rev. 992561

5. Maurya M R, Khurana S, Shailendra, Azam A, Zhang W and Rehder D 2003 Eur. J. Inorg. Chem. 1966

6. Ligtenbarg A G J, Hage R and Feringa B L 2003 Coord. Chem. Rev. 23789

7. Conte V, Furia F D and Licini G 1997 Appl. Catal. A157 335

8. Maurya M R, Kumar M, Titinchi S J J, Abbo H S and Chand S 2003 Catal. Lett. 9786

9. Maurya M R, Saklani H, Kumar A and Chand S 2004 Catal. Lett. 93121

10. Maurya M R, Kumar A, Manikandan P and Chand S 2004 Appl. Catal. A45 277

11. Maurya M R, Saklani H and Agarwal S 2004 Catal. Commun. 5563

12. Butler A 1999 Bioinorganic catalysis 2nd edn (eds) J Reedijk and E Boiwman (New York: Marcel Dekker) ch. 5

13. Butler A 1999 Coord. Chem. Rev. 18717

14. Rehder D 2001 J. Inorg. Biochem. 80133

15. Janas Z and Sobota P 2005 Coord. Chem. Rev. 2492133

16. Weyand M, Hecht H J. Kei $\beta$ M, Liaud M F, Vilter H and Schomburg D 1999 J. Mol. Biol. 293595

17. Isupov M I, Dalby A R, Brindley A A, Izumi Y Tanabe T, Murshudov G N and Littlechild J A $2000 \mathrm{~J}$. Mol. Biol. 2991035

18. Messershmidt A and Wever R 1996 Proc. Natl. Acad. Sci. USA 93392

19. Kuchta L, Sivak M, Marek J, Pavelcik F and Cãsny M 1999 New J. Chem. 2343

20. Messershmidt A, Prade L and Wever R 1997 Bio. Chem. 378309 
21. Franssen M C R 1994 Biocatalysis 1087

22. (a) Franssen M C R 1994 Catal. Today 22 441; (b) Colpas G J, Hamstra B J, Kampf J W and Pecoraro V L 1996 J. Am. Chem. Soc. 118 3469; (c) Hamstra B J, Colpas G J and Pecoraro V L 1998 Inorg. Chem. 37949

23. Satoni G, Licini G M and Rehdar D 2003 Chem. Eur. J. 94700

24. Smith T S II and Pecoraro V L 2002 Inorg. Chem. 41 6754

25. Maurya M R 2003 Coord. Chem. Rev. 237163

26. Maura M R, Khurana S, Schulzke C and Rehder D 2001 Eur. J. Inorg. Chem. 779

27. Rehder D 1992 Transition metal nuclear magnetic resonance (ed.) P S Pregosin (New York: Elsevier) p. 1
28. Maurya M R, Agarwal S, Bader C, Ebel M and Rehder D 2005 Dalton Trans. 537

29. Plass W, Pohlmann, A and Yozgatli H K $2000 \mathrm{~J}$. Inorg. Biochem. 80181

30. Hirao T 1997 Chem. Rev. 972707

31. Maurya M R, Agarwal S, Bader C and Rehder D 2005 Eur. J. Inorg. Chem. 147

32. Maurya M R, Khurna S, Zhang W and Rehder D 2002 Eur. J. Inorg. Chem. 3015

33. Maurya M R, Agarwal S, Abid M, Azam A, Bader C, Ebel M and Rehder D 2006 Dalton Trans. 937

34. Deflon V D, De Oliveira D M, de Sousa G F, Batista A A, Dinelli L R and Castellano E E 2002 Z. Anorg. Allg. Chem. 628140 